\title{
PEGARUH PERSEPSI KEMANFAATAN DAN PERSEPSI KEMUDAHAN PENGGUNAAN TERHADAP SIKAP PENGGUNAAN RESEP ELEKTRONIK
}

\author{
Rizki Rijatullah 1*, Agus Suroso ${ }^{2}$, Lantip Rujito ${ }^{3}$ \\ ${ }^{1}$ Program Pascasarjana Magister Manajemen Universitas Jenderal Soedirman, Indonesia \\ ${ }^{*}$ Email corresponding author: rizki.rijatullah@yahoo.com
}

\begin{abstract}
Abstrak
Penelitian ini merupakan penelitian asosiatif dengan pendekatan cross sectional pada seluruh dokter di RSUD Margono Soekarjo Purwokerto. Tujuan dari penelitian ini yaitu untuk menguji pengaruh persepsi kemanfaatan dan persepsi kemudahan penggunaan terhadap sikap penggunaan resep elektronik oleh dokter di RSUD Prof. Dr. Margono Purwokerto dengan dukungan organisasi sebagai variabel mediasi. Jumlah responden dalam penelitan ini adalah 73 responden. Dalam penelitian ini sampel diambil dengan cara nonprobability sampling yaitu dengan teknik random sampling. Pengumpulan data yang digunakan dalam penelitian ini adalah dengan menggunakan kuesioner yang dibagikan secara langsung. Sedangkan analisis data dalam penelitian ini menggunaan regresi linier dan uji efek mediasi menggunakan uji Sobel. Berdasarkan hasil penelitian dan analisis data menunjukan bahwa : (1) Persepsi kemanfaatan berpengaruh terhadap sikap penggunaan resep elektronik oleh dokter di RSUD Prof. Dr. Margono Soekarjo Purwokerto, (2) Persepsi kemudahan penggunaan berpengaruh terhadap sikap penggunaan resep elektronik oleh dokter di RSUD Prof. Dr. Margono Soekarjo Purwokerto, (3) Dukungan organisasi berpengaruh terhadap sikap penggunaan resep elektronik oleh dokter di RSUD Prof. Dr. Margono Soekarjo Purwokerto, (4) Dukungan organisasi memediasi antara persepsi kemanfaatan terhadap sikap penggunaan resep elektronik oleh dokter di RSUD Prof. Dr. Margono Soekarjo Purwokerto, (5) Dukungan organisasi memediasi antara persepsi kemudahan penggunaan terhadap sikap penggunaan resep elektronik oleh dokter di RSUD Prof. Dr. Margono Soekarjo Purwokerto melalui dukungan.
\end{abstract}

Kata Kunci: Persepsi kemanfaatan, Persepsi kemudahan, Sikap terhadap penggunaan, Dukungan organisasi, Resep elektronik.

\begin{abstract}
This research is an associative research with a cross sectional approach to all doctors in Margono Soekarjo Hospital Purwokerto. The purpose of this study is to examine the effect of perceived usefulness and perceived ease of use on the attitude of using electronic prescriptions by doctors at Prof. Dr. Margono Purwokerto with organizational support as a mediating variable. The number of respondents in this research was 73 respondents. In this study the sample was taken by means of nonprobability sampling, that is by random sampling technique. Data collection used in this study was to use a questionnaire that was distributed directly. While the data analysis in this study uses linear regression and the mediation effect test uses the Sobel test. Based on the results of research and data analysis shows that: (1) Perceived usefulness affects the attitude of the use of electronic prescriptions by doctors in RSUD Prof. Dr. Margono Soekarjo Purwokerto, (2) Perceived ease of use affects the attitude of using electronic prescriptions by doctors at Prof. Hospital Dr. Margono Soekarjo Purwokerto, (3) Organizational support has an influence on the attitude of the use of electronic prescriptions by doctors at the RSUD Prof. Dr. Margono Soekarjo Purwokerto, (4) Organizational support mediates between perceptions of the usefulness of attitudes to the use of electronic prescriptions by doctors at RSUD Prof. Dr. Margono Soekarjo Purwokerto, (5) Organizational support mediates between perceptions of ease of use and attitudes to the use of electronic prescriptions by doctors in RSUD Prof. Dr. Margono Soekarjo Purwokerto through support.
\end{abstract}

Keywords: Perception of expediency, Perception of convenience, Attitude towards use, Organizational support, Electronic prescription. 


\section{PENDAHULUAN}

Teknologi informasi hingga saat ini berkembang dengan pesat. Perkembangan teknologi ini juga terjadi di bidang kesehatan. Teknologi informasi berbasis komputer sekarang banyak digunakan di bidang kesehatan, di antaranya rekam medis elektronik (Holroyd-Leduc et al., 2011). Sistem rekam medis elektronik sangat potensial untuk meningkatkan kualitas pelayanan kesehatan dan meningkatkan efisiensi sistem pelayanan kesehatan. Rekam medis elektronik bermanfaat sebagai dokumentasi elektronik, peresepan obat, permintaan tes kesehatan, manajemen pengingat perawatan kesehatan, dan lainnya. Penggunaan rekam medis elektronik secara signifikan dapat menurunkan beban kerja dokter dan kesalahan medis (Aldrich, 2010).

Resep elektronik sangat potensial untuk menurunkan kesalahan dalam pengobatan. Hasil penelitian dari 10.070 resep yang ditulis, 530 diidentifikasi sebagai kesalahan dalam pengobatan. Lebih dari setengah kesalahan dalam pengobatan yang teridentifikasi terdapat setidaknya satu dosis obat yang hilang. Resep elektronik dapat mencegah 84\% dosis yang hilang (Kohn et al., 2000).

Resep elektronik adalah metode yang kuat untuk mencegah kesalahan dalam pengobatan yang disebabkan oleh kesalahan interpertasi seperti pada resep yang ditulis tangan. Resep elektronik dapat memastikan bahwa obat, dosis, bentuk sediaan, jumlah, waktu pemberian yang tertulis adalah benar dan dapat juga mengetahui adanya interaksi obat, adanya alergi terhadap obat tertentu dan kesesuaiannya dengan kondisi pasien (Widiastuti, 2013).

Salah satu model yang digunakan untuk mengukur penerimaan adalah Technology Acceptance Model (TAM). Technology Acceptance Model (TAM) merupakan model yang populer digunakan untuk mengukur adopsi teknologi informasi mengenai penggunaan maupun penerimaan sistem informasi (Dalbouh, 2013). Kegunaan dan kemudahan penggunaan secara signifikan mempengaruhi sikap terhadap penggunaan sistem informasi (Kim dan Hyung, 2014).

Penelitian ini memodifikasi Technology Acceptance Model (TAM), dengan menggunakan penerimaan pemakai teknologi ditentukan oleh dua variabel kunci yang diusulkan oleh Davis (1989) yaitu persepsi kemanfaatan dan persepsi kemudahan penggunaan terhadap sikap penggunaan dengan dukungan organisasi sebagai variabel mediasi. Persepsi kemanfaatan adalah tingkat kepercayaan individu bahwa penggunaan teknologi akan meningkatkan kinerjanya, dan persepsi kemudahan penggunaan adalah tingkat kepercayaan individu bahwa penggunaan teknologi membuatnya lebih mudah. Sikap terhadap penggunaan didefinisikan oleh Davis (1989) sebagai perasaan-perasaan positif atau negatif dari seseorang jika harus melakukan perilaku yang akan ditentukan. Sehingga, sikap seseorang dalam menyukai atau tidak menyukai terhadap penggunaan dalam suatu produk ataupun sistem, merupakan sikap seseorang dalam mengimplementasikan suatu produk agar dapat digunakan untuk memudahkan pekerjaaanya.

Kepuasan pengguna langsung dipengaruhi oleh persepsi kemanfaatan dan niat terhadap pengguna untuk terus menggunakannya. Sikap seorang individu dalam merima suatu sistem atau produk baru juga diduga dipengaruhi oleh dukungan organisasi yang menaunginya, dalam hal ini RSUD Margono Soekarjo. Dukungan organisasi merupakan konsep yang penting dalam literatur manajemen. Dukungan organisasi dapat berarti menghargai kontribusi karyawan, mendengar keluhan, merasa bangga akan hasil kinerja atau prestasi karyawannya dan memenuhi kebutuhan karyawan (Rhoades et al., 2001).

Kondisi yang terjadi di RSUD Prof. Dr. Margono Soekarjo Purwokerto pada saat studi observasi pendahuluan, peneliti mengetahui bahwa seluruh dokter sudah diwajibkan untuk menggunakan resep elektronik. RSUD Prof. Dr. Margono Soekarjo merupakan rumah sakit rujukan Provinsi Jawa Tengah. Rumah sakit ini bertugas sebagai rumah sakit rujukan regional (RSUD Prof. Dr. Margono, 2017). Sistem informasi kesehatan telah dikembangkan di RSUD Prof. 
Dr. Margono dalam beberapa tahun terakhir. Instalasi rawat jalan RSUD Prof. Dr. Margono telah menerapkan sistem informasi kesehatan berbasis elektronik dan sistem peresepan obat berbasis elektronik (CPOE) sehingga dokter tidak perlu menuliskan resep secara manual.

Berbagai penelitian menunjukkan bahwa peresepan obat berbasis elektronik mempunyai dampak positif pada mutu pelayanan kesehatan seperti penelitian yang dilakukan oleh Bizovi (2002) menyebutkan bahwa penggunan komputer dalam peresepan obat menyebabkan kesalahan 3 kali lebih sedikit dan klarifikasi 5 kali lebih sedikit dibandingkan peresepan dengan menggunakan tangan. Penelitian Kusumarini (2011) di sebuah RS swasta di Yogyakarta menyimpulkan bahwa resep elektronik dapat meminimalkan risiko pada fase prescribing (kesalahan baca akibat tulisan dokter yang jelek dan pemilihan dosis terkecil) dan transcribing (kesalahan yang sering terjadi akibat tidak dituliskannya jumlah obat dan dosis) serta mengurangi waktu tunggu pasien. Hal ini diperkuat oleh Radley, et al. (2013) yang menyebutkan penggunaan peresepan obat berbasis elektronik pada tahun 2008 di rumah sakit Amerika Serikat mampu mengurangi tingkat kesalahan sebesar $48 \%$.

Rumusan masalah dalam penelitian ini adalah "apakah persepsi kemanfaatan dan kemudahan penggunaan berpengaruh terhadap sikap penggunaan resep elektronik oleh dokter di RSUD Margono Soekarjo Purwokerto dengan dukungan organisasi sebagai variabel mediasi?". Sedangkan tujuan dalam penelitian ini adalah untuk menguji pengaruh antara persepsi kemanfaatan dan kemudahan penggunaan terhadap sikap penggunaan resep elektronik oleh dokter di RSUD Margono Soekarjo Purwokerto dengan dukungan organisasi sebagai variabel mediasi.

\section{TINJAUAN PUSTAKA DAN PERUMUSAN HIPOTESIS \\ Resep Elektronik}

Peresepan elektronik adalah teknologi elektronik yang memungkinkan dokter dan praktisi medis lainnya untuk menulis resep elektronik dan mengirimkannya ke komputer apotek yang dikehendaki yang tergabung dalam jaringan peresepan elektronik, langsung dari tempat praktik dokter atau tempat perawatan. Pengertian lain Peresepan elektronik adalah proses elektronik yang menghasilkan dan mengirimkan permintaan resep elektronik dari dokter untuk dikirimkan oleh provider ke komputer apotek yang dikehendaki langsung dari tempat perawatan atau tempat praktek dokter. Dokter tidak perlu menulis obat yang akan diberikan kepada pasien dengan tulisan tangan di atas kertas resep, melainkan langsung menuliskannya di komputer. Pada peresepan elektronik, resep elektronik dikirim melalui sistem jaringan internet tertutup (intranet) yang aman. Dengan demikian, setiap pengguna akses yang akan memasuki sistem tersebut harus melakukan autentikasi terlebih dahulu yang memerlukan nama pengguna dan kata kunci atau SecureID yang lain (Farida et al., 2017).

\section{Technology Acceptance Model (TAM)}

Technology Acceptance Model (TAM) atau model penerimaan teknologi merupakan salah satu teori tentang penggunaan sistem teknologi informasi yang dianggap sangat berpengaruh dan umumnya digunakan untuk menjelaskan penerimaan individual terhadap penggunaan sistem teknologi informasi. TAM pertama dikembangkan oleh Davis (1985) berdasarkan model Theory of Reasoned Action (TRA). Kelebihan TAM yang paling penting adalah TAM merupakan model parsimoni, yaitu model yang sederhana tetapi valid. Selain itu, TAM juga telah diuji dengan banyak penelitian yang hasilnya TAM merupakan model yang baik khususnya jika dibandingkan dengan model TRA dan TPB (Jogiyanto, 2008). TAM diyakini mampu meramalkan penerimaan pemakai terhadap teknologi berdasarkan dampak dari dua faktor, yaitu persepsi kemanfaatan 
(perceived usefullness) dan persepsi kemudahan penggunaan (perceived ease of use) (Davis, 1989). Gambar 1 yang menunjukan model Technology Acceptance Model (TAM).

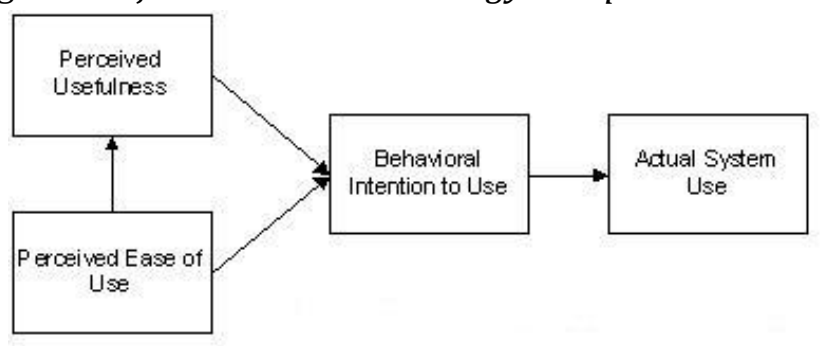

Gambar 1. Technology Acceptance Model (TAM)

Sumber : Davis et al., 1989 \& Venkatesh et al., 2003

\section{Persepsi Kemanfaatan}

Persepsi kemanfaatan dapat diartikan sebagai derajat di mana individu percaya bahwa penggunaan sebuah teknologi tertentu akan mendorong kinerja tugasnya (Huang et al., 2000). Jadi konsep persepsi kemanfaatan menunjukkan keyakinan pemakai pada kontribusi sistem informasi terhadap kinerja pemakai. Persepsi kemanfaatan merupakan dimensi kinerja (performance) yang diinterpretasikan sebagai effect of the model on the manager's job performance. Hal ini berartinya manfaat atau kegunaan adalah salah satu bagian dari kinerja itu sendiri. Sebuah sistem pada dasarnya dibuat untuk mengatur dan mendukung anggota organisasi dalam pencapaian tujuan. Sebuah sistem yang tidak dapat membantu kinerja pekerjaan orang maka tidak akan disukai untuk diterimaHasil penelitian TAM menunjukan bahwa persepsi kemanfaatan dipengaruhi oleh persepsi kemudahan penggunaan berhubungan dengan pelatihan, dukungan komputasi dan manajemen. Korelasi hubungan persepsi kemanfaatan terhadap perilaku penggunaan sistem informasi lebih kuat dari pada persepsi kemudahan penggunaan dan dapat untuk menentukan self- reported usage sistem informasi sehingga berpengaruh langsung terhadap penggunaan sistem informasi. Suatu penelitian menemukan bukti secara signifikan bahwa persepsi kemanfaatan sebagai pembentukan sikap penggunaan (Venkatesh et al., 2001).

\section{Persepsi Kemudahan Penggunaan}

Persepsi kemudahan penggunaan merupakan tingkatan kepercayaan individu bahwa menggunakan sebuah teknologi akan terbebas dari usaha. Konsep ini memberikan pengertian bahwa bila sistem informasi mudah digunakan, maka pengguna akan cenderung untuk menggunakan sistem informasi tersebut. Persepsi kemudahan penggunaan merupakan tingkat kepercayaan seseorang bahwa penggunaan sistem informasi merupakan hal yang mudah dan tidak memerlukan usaha keras dari pemakainya. Kemudahan ini akan mengurangi tenaga, pikiran, dan waktu yang digunakan untuk mempelajari dan menggunakan sistem informasi. Kemudahan penggunaan merefleksikan individu yang dapat berinteraksi dengan suatu software tertentu. Hal ini menggambarkan bahwa individu akan lebih suka untuk berinteraksi dengan teknologi baru jika mereka mempresepsikan bahwa usaha kognitif mereka relatif kecil selama berinteraksi. Kemudahan penggunaan merupakan proses pengharapan dan persepsi kemanfaatan merupakan hasil expectancy. Sehingga kemudahan penggunaan diharapkan dapat mempengaruhi persepsi kemanfaatan karena semakin mudah sebuah teknologi digunakan, maka semakin berguna teknologi tersebut (Venkatesh et al., 2001).

\section{Sikap terhadap Penggunaan}


Sikap terhadap penggunaan dalam TAM dikonsepkan sebagai sikap terhadap penggunaan sistem yang berbentuk penerimaan atau penolakan sebagai dampak bila seseorang menggunakan suatu teknologi dalam pekerjaannya (Davis, 1989). Sikap pada penggunaan sesuatu menurut Aakers dan Myers (1997) adalah sikap menyukai atau tidak menyukai terhadap penggunaan dalam suatu produk. adalah sikap menyukai atau tidak menyukai terhadap suatu produk ini dapat digunakan untuk memprediksi perilaku niat seseorang dalam menggunakan suatu produk atau tidak menggunakannya. Sikap terhadap penggunaan teknologi didefinisikan sebagai evaluasi dari pemakai tentang ketertarikannya dalam menggunakan teknoologi (Davis, 1989). Variabel sikap terhadap penggunaan bisa disebut sebagai variabel penghubung antara dua variabel persepsi utama TAM dan variabel niat perilaku menggunakan teknologi.

\section{Dukungan Organisasi}

Dukungan organisasi merupakan dukungan organisasi yang dipersepsikan dengan keyakinan global mengenai sejauh mana organisasi menilai kontribusi, memperhatikan kesejahteraan, mendengar keluhan, memperhatikan kehidupan dan mempertimbangkan tujuan yang akan dicapai serta dapat dipercaya untuk memperlakukan karyawan dengan adil (Eisenberger et al., 2002). Dukungan organisasi bergantung pada proses atributional yang digunakan untuk menunjukkan komitmen yang dilakukan oleh orang lain dalam suatu hubungan sosial. Dukungan organisasional dipengaruhi oleh interaksi seseorang dengan organisasi dimana organisasi tersebut memberikan pujian, dukungan dan persetujuan. Dukungan organisasi dapat dipengaruhi oleh berbagai aspek dari perlakuan organisasi terhadap karyawan, yang pada akhirnya mempengaruhi interpretasi karyawan mengenai motif-motif organisasional yang menjadi dasar perlakuan itu. Hal ini menunjukkan bahwa derajat dukungan yang karyawan inginkan dari organisasi bervariasi bergantung dari situasinya (Eisenberger et al., 2002). Menurut Wayne et al., (1997) banyak hal yang bisa dilakukan oleh organisasi dalam memberikan penghargaan terhadap karyawannya. Hal yang paling menonjol bagi karyawan adalah dipromosikan ke posisi yang lebih tinggi, penghargaan terhadap peningkatan kinerja biasanya berkaitan dengan meningkatnya upah. Pada penelitian Armeli et al.,; Lynch et al., (dalam Eisenberger et al., 2002) dukungan organisasi dipengaruhi pula oleh kebijakan dan keputusan yang menunjukan perhatian organisasi terhadap kesejahteraan karyawan. Dukungan organisasi dapat memperkuat pengharapan karyawan bahwa organisasi akan memberi pemahaman yang simpatik dan bantuan material untuk berhubungan dengan situasi stres di tempat kerja atau di rumah, yang akan membantu memenuhi kebutuhan terhadap dukungan emosional (Rhoades et al., 2001).

\section{Kesalahan Pengobatan}

Kesalahan pengobatan (medicatoin error) merupakan kejadian yang menyebabkan atau berakibat pada pengobatan yang tidak tepat atau membahayakan pasien yang sebenarnya dapat dihindari. Terjadi atau tidaknya suatu kesalahan dalam pelayanan pengobatan terhadap pasien telah menjadi indikator penting dalam keselamatan pasien. Medication error merupakan jenis medical erroryang paling sering dan banyak terjadi (Aronson, 2009). Kesalahan pengobatan (medication error) dapat terjadi pada 4 fase, yaitu kesalahan peresepan (prescribing error), kesalahan penerjemahan resep (transcribing erorr), kesalahan menyiapkan dan meracik obat (dispensing erorr), dan kesalahan penyerahan obat kepada pasien (administration error).

\section{Hipotesis}


Hasil penelitian sebelumnya menunjukan bahwa perceived usefulness berpengaruh secara positif dan signifikan terhadap penggunaan sistem informasi (Davis, 1989). Penelitian sebelumnya juga menunjukan bahwa perceived usefulness signifikan dan penting dalam mempengaruhi sikap penggunaan (attitude towards using), minat dan perilaku dalam penggunaan teknologi dibanding faktor yang lain. Mathieson (1991) mendefinisikan sikap terhadap penggunaan (attitude towards using) sebagai evaluasi pemakai tentang ketertarikannya menggunakan sistem. Kemudahan penggunaan (perceived ease of use) menunjukan tingkat dimana seseorang menyakini bahwa penggunaan sistem informasi adalah mudah dan tidak memerlukan usaha keras dari pemakainya untuk bisa menggunakannya (Davis et al., 1989). Apabila sistem informasi mudah digunakan, maka pengguna akan cenderung untuk menggunakan sistem informasi tersebut. Oleh karena itu, dalam mengembangkan suatu sistem informasi perlu Hal ini juga didukung secara empiris di bidang TAM yang menjelaskan bahwa kemudahan penggunaan (perceived ease of use) merupakan anteseden variabel (perceived usefulness, attitude towards using, dan behavior intention to use).

Penelitian yang dilakukan oleh Hanggono (2015) ditemukan bahwa peresepsi kemanfaatan (perceived usefulness) memiliki pengaruh signifikan terhadap sikap penggunaan (Attitude toward using). Dukungan organisasi (perceived organizational support) merupakan dukungan organisasi yang dipersepsikan dengan keyakinan mengenai sejauh mana organisasi menilai kontribusi, memperhatikan kesejahteraan, mendengar keluhan, memperhatikan kehidupan dan mempertimbangkan tujuan yang akan dicapai serta dapat dipercaya untuk memperlakukan karyawan dengan adil (Eisenberger et al., 2002). Dukungan organisasi (perceived organizational support) bergantung pada proses atributional yang digunakan untuk menunjukkan komitmen yang dilakukan oleh orang lain dalam suatu hubungan sosial. Dukungan organisasional didukung oleh interaksi seseorang dengan organisasi dimana organisasi tersebut memberikan pujian, dukungan dan persetujuan. Sedangkan Rhoades et al., (2001) menyatakan bahwa dukungan organisasi berhubungan dengan kebijakan organisasi. Kebijakan organisasi disini dapat dilihat melalui sikap (attitude) seseorang dalam menerima suatu hal.

Dukungan organisasi dapat memperkuat hubungan antara perilaku niat dan penggunaan teknologi resep elektronik. Dukungan dari organisasi menandakan bahwa karyawan akan berkontribusi kepada organisasi secara timbal balik jika mereka berpikir bahwa organisasi mereka peduli terhadap kesejahteraan mereka dan mendukung kontribusi mereka (Eisenberger et al., 1986). Demikian pula, teori pertukaran sosial juga membenarkan bahwa karyawan yang kontribusi dihargai dan didukung akan menunjukkan lebih banyak kecenderungan dan motivasi terhadap pekerjaan mereka (Eisenberger \& Stinglhamber, 2011). Sedangkan sikap terhadap penggunaan (attitude towards using) telah dianggap sebagai anteseden langsung yang memiliki pengaruh yang signifikan terhadap adopsi teknologi online (Khan et al., 2017; Tarhini et al., 2016; Venkatesh et al., 2012). Sehingga dukungan organisasi (perceived organizational support) diduga memediasi antara persepsi kemanfaatan (perceived usefulness) terhadap sikap terhadap penggunaan (attitude towards using).

Taylor (1995) menyatakan bahwa perceived ease of use memiliki pengaruh terhadap sikap (attitude). Sikap terhadap penggunaan (attitude toward using), didefinisikan sebagai evaluasi dari pemakai tentang ketertarikannya dalam menggunakan uatu sistem (Davis, 1989). Dukungan organisasi (perceived organizational support) memiliki mekanisme yang mengikat bagi karyawan (dokter) dan rumah sakit. Uppal (2017) menilai efek moderasi perceived organizational support antara neurotisisme dan kinerja pekerjaan. Kurtessis et al., (2015) menyatakan bahwa dukungan organisasi (perceived organizational support) memulai pertukaran sosial proses dimana karyawan membantu organisasi mereka dengan bahagia dan menemukan bahwa itu memiliki 
peran sentral dalam hubungan karyawan dengan organisasi. Para dokter memerlukan dukungan dari organisasi mereka untuk mengaktualisasikan resep elektronik untuk masa depan sektor kesehatan yang lebih baik. Hoque et al., (2016) menyatakan bahwa perilaku (attitude) pasien dan dokter mengarah pada penerimaan teknologi di Bangladesh. Oleh karena itu, penulis menduga bahwa niat perilaku dokter akan mengarahkan mereka untuk mengadopsi resep elektronik.

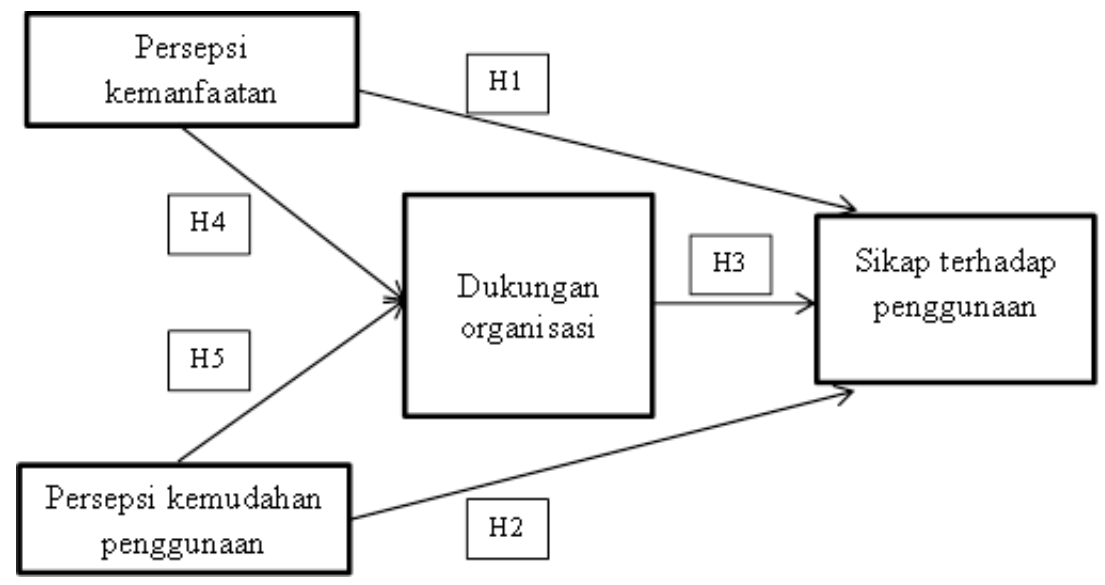

Gambar 2. Kerangka Pemikiran

Hipotesis dalam penelitian ini berdasarkan rumusan masalah, tinjauan pustaka dan penelitian terdahulu adalah:

$\mathrm{H}_{1}=$ Persepsi kemanfaatan berpengaruh terhadap sikap penggunaan resep elektronik oleh dokter di RSUD Prof. Dr. Margono Soekarjo Purwokerto

$\mathrm{H}_{2}=$ Peresepsi kemudahan penggunaan berpengaruh terhadap sikap penggunaan resep elektronik oleh dokter di RSUD Prof. Dr. Margono Soekarjo Purwokerto

$\mathrm{H}_{3}=$ Dukungan organisasi berpengaruh terhadap sikap penggunaan resep elektronik oleh dokter di RSUD Prof. Dr. Margono Soekarjo Purwokerto

$\mathrm{H}_{4}=$ Dukungan organisasi memediasi antara persepsi kemanfaatan terhadap sikap penggunaan resep elektronik oleh dokter di RSUD Prof. Dr. Margono Soekarjo Purwokerto

$\mathrm{H}_{5}=$ Dukungan organisasi memediasi antara kemudahan penggunaan terhadap sikap penggunaan resep elektronik oleh dokter di RSUD Prof. Dr. Margono Soekarjo Purwokerto

\section{METODE PENELITIAN}

Jenis penelitian ini adalah asosiatif, karena dalam penelitian ini penelitian ingin mengetahuni hubungan atau pengaruh dari variabel-variabel yang diteliti (Sugiyono, 2002). Rancangan penelitian ini adalah penelitian cross sectional. Pada penelitian ini pengumpulan data dilakukan pada satu waktu dimana fenomena yang diteliti adalah selama satu periode pengumpulan data (Swarjana, 2016).

Populasi yang digunakan dalam penelitian ini adalah seluruh dokter di RSUD Margono Soekarjo Purwokerto yang berjumlah 89 dokter.

Ukuran sampel dicari menggunakan rumus Solvin sebagai berikut:

$\mathrm{n}=\frac{N}{1+N\left(e^{2}\right)}$

Keterangan: 
$\mathrm{n}=$ Jumlah Sampel

$\mathrm{N}=$ Jumlah Populasi (responden)

$\mathrm{e}^{2}=$ Margin error yang diperkenankan $(0,05)$

Sehingga sampel dalam penelitian ini adalah:

$\mathrm{n}=\frac{89}{1+89\left(0,05^{2}\right)}=72,8=$ dibulatkan menjadi 73 responden

Dalam penelitian ini sampel diambil dengan menggunakan teknik random sampling. Teknik random sampling atau metode acak merupakan teknik dimana anggota populasi memiliki kesempatan yang sama untuk diikut sertakan pada sample penelitian secara proporsional (Sugiyono, 2009). Pengumpulan data yang digunakan dalam penelitian ini adalah dengan menggunakan kuesioner yang dibagikan kepada dokter yang menjadi responden dalam penelitian ini. Pengukuran dilakukan dengan skala Likert (summated rating), yaitu skala yang digunakan secara luas dengan meminta responden menandai derajat persetujuan sesuai atau ketidaksetujuan masing-masing dari serangkaian pertanyaan mengenai obyek stimulus (Malhotra, 2009). Sedangkan analisis data dalam penelitian ini menggunakan regresi linier dan uji efek mediasi menggunakan uji Sobel.

\section{HASIL DAN PEMBAHASAN}

Uji Asumsi Klasik

\section{a. Uji Normalitas}

Tabel 1. Hasil Uji Normalitas

\begin{tabular}{cc}
\hline Variabel & Standardized Residual \\
\hline Kolmogorov-Smirnov $Z$ & 0,551 \\
Asymp. Sig. (2-tailed) & 0,922 \\
\hline
\end{tabular}

Sumber: Data diolah, 2019.

Dari uji normalitas kolmogorov-Smirnov didapatkan hasil nilai Kolmogorov-Smirnov Z sebesar 0,551 dengan tingkat signifikan lebih besar dari 0,05. Pada Tabel 4.11 diperoleh hasil Sig (2-tail $=0,922>\alpha(0,05)$ maka nilai residual terstandarisasi dikatakan menyebar dengan normal, sehingga model regresi lolos uji asumsi normalitas.

\section{b. Uji Multikolinieritas}

Tabel 2. Hasil Uji Multikolinieritas

\begin{tabular}{ccc}
\hline Variabel & \multicolumn{2}{c}{ Collinearity } \\
& Tolatistics \\
& 0,501 & VIF \\
\hline Persepsi kemanfaatan & 0,556 & 1,998 \\
Persepsi kemudahan penggunaan & 0,437 & 1,799 \\
Dukungan organisasi & 2,286 \\
\hline
\end{tabular}

a. Dependent Variable: Sikap terhadap penggunaan resep elektronik Sumber: Data diolah, 2019.

Berdasarkan uji diatas nilai tolerance dari variabel independen yang terdiri dari persepsi kemanfaatan, persepsi kemudahan penggunaan dan dukungan organisasi secara berturut-turut $(0,501,0,556$ dan 0,437$)$. Sedangkan nilai VIF adalah $(1,998,1,799$, dan 2,286). Nilai tersebut sesuai dengan syarat gejala multikoleniaritas (tolerance $>0,10$ atau VIF $<10$ ). Atau dengan kata lain variabel independen penelitian bebas dari gejala multikoleniaritas. 


\section{c. Uji Heteroskedastisitas}

Tabel 3. Hasil Uji Heteroskedastisitas

\begin{tabular}{ccc}
\hline Variabel & t & sig \\
\hline Persepsi kemanfaatan & $-1,069$ & 0,289 \\
Persepsi kemudahan penggunaan & 1,299 & 0,198 \\
Dukungan organisasi & 1,189 & 0,238 \\
\hline
\end{tabular}

a. Dependent Variable: ABRESID

Sumber: Data diolah, 2019.

Berdasarkan hasil uji heteroskesatisitas bahwa model regresi terbebas dari heteroskedastisitas karena variabel persepsi kemanfaatan, persepsi kemudahan penggunaan dan dukungan organisasi mempunyai nilai signifikansi dari uji t menunjukkan nilai $>\alpha$. $(0,05)$. Artinya data tersebut tidak heteros.

\section{Analisis Regresi}

Tabel 4. Hasil Analisis Regresi

\begin{tabular}{ccccc}
\hline Variabel Penelitian & Koefisien & t & Sig & Simpulan \\
\hline Persepsi kemanfaatan & 0,416 & 5,661 & 0,000 & Signifikan \\
Persepsi kemudahan penggunaan & 0,171 & 2,180 & 0,033 & Signifikan \\
Dukungan organisasi & 0,305 & 2,351 & 0,022 & Signifikan \\
F & \multicolumn{4}{c}{54,748} \\
Sig & \multicolumn{3}{c}{$0,000^{\mathrm{b}}$} \\
$\mathrm{R}^{2}$ & \multicolumn{3}{c}{0,691} \\
\hline
\end{tabular}

a. Dependent Variable: Sikap terhadap penggunaan resep elektronik

Sumber: Data diolah, 2019.

Berdasarkan analisis regresi didapatkan nilai $\mathrm{F}$ hitung 54.748 dengan nilai signifikansi 0,000 $(<0,05)$, maka dapat disimpulkan bahwa terdapat pengaruh secara bersama-sama (simultan) antara persepsi kemanfaatan, persepsi kemudahan penggunaan dan dukungan organisasi terhadap sikap penggunaan resep elektronik oleh dokter di RSUD Prof. Dr. Margono Soekarjo Purwokerto. Nilai R square variabel independen terhadap kinerja sebesar 0,691 artinya besarnya pengaruh secara simultan variabel independen persepsi kemanfaatan, persepsi kemudahan penggunaan dan dukungan organisasi terhadap sikap penggunaan resep elektronik oleh dokter di RSUD Prof. Dr. Margono Soekarjo Purwokerto sebesar 69,1\% dan sisanya yaitu sebesar 30,9\% dipengaruhi oleh variabel lain yang tidak diteliti dalam model penelitian ini.

\section{Uji Efek Mediasi}

Tabel 5. Hasil uji sobel hubungan persepsi kemanfaatan terhadap sikap penggunaan resep elektronik yang dimediasi oleh dukungan organisasi

\begin{tabular}{cc}
\hline Sobel & Signifikansi \\
\hline Sobel test statistic & 2,11993764 \\
One-tailed probability & 0,01700565 \\
Two-tailed probability & 0,03401130 \\
\hline
\end{tabular}

Sumber: Data diolah, 2019. 
Berdasarkan hasil uji sobel, dapat diketahuai bahwa variabel persepsi kemanfaatan (perceived usefulness) berhubungan terhadap sikap terhadap penggunaan (attitude towards using) yang melalui dukungan organisasi (perceived organizational support). Hasil ini menunjukkan hipotesis empat $\left(\mathrm{H}_{4}\right)$ diterima. Kemudahan penggunaan (perceived usefulness) persepsian merupakan salah satu faktor dalam model TAM yang telah diuji dalam penelitian Davis et al. (1989). Hasil penelitian tersebut menunjukkan bahwa faktor ini terbukti dapat menjelaskan alasan seseorang dalam menggunakan sistem informasi dan menjelaskan bahwa sistem baru yang sedang dikembangkan diterima oleh pengguna.

\section{Tabel 6. Hasil uji sobel hubungan persepsi kemudahaan penggunaan terhadap sikap penggunaan resep elektronik yang dimediasi oleh dukungan organisasi}

\begin{tabular}{cc}
\hline Sobel & Signifikansi \\
\hline Sobel test statistic & 2,00722765 \\
One-tailed probability & 0,02236271 \\
Two-tailed probability & 0,04472543 \\
\hline
\end{tabular}

Sumber: Data diolah, 2019.

Berdasarkan hasil uji sobel, dapat diketahuai bahwa variabel kemudahaan penggunaan (perceived ease of use) berhubungan terhadap sikap terhadap penggunaan (attitude towards using) melalui dukungan organisasi (perceived organizational support), yang berarti bahwa Hipotesis $5\left(\mathrm{H}_{5}\right)$ diterima. Konsep perceived ease of use menunjukan tingkat dimana seseorang menyakini bahwa penggunaan sistem informasi adalah mudah dan tidak memerlukan usaha keras dari pemakainya untuk bisa menggunakannya. Konsep ini mencakup kejelasan tujuan penggunaan sistem informasi dan kemudahan penggunaan sistem untuk tujuan sesuai dengan keinginan pemakai (Davis et al., 1989).

\section{Pengujian Hipotesis}

Hipotesis 1 menyatakan bahwa persepsi kemanfaatan berpengaruh terhadap sikap penggunaan resep elektronik oleh dokter di RSUD Prof. Dr. Margono Soekarjo Purwokerto. Hasil analisis regresi Tabel 4 menunjukan nilai t hitung untuk variabel persepsi kemanfaatan 5,661 dengan nilai signifikansi 0,000, karena nilai t hitung lebih besar dari t tabel 1,993 $(5,661>1,993)$ dan nilai signifikansi kurang dari 0,05 $(0,000<0,05)$, maka dapat disimpulkan bahwa hipotesis tersebut diterima. Hasil tersebut sejalan dengan penelitian yang dilakukan oleh Amin et al. (2014) yang menyatakan bahwa persepsi kemanfaatan berpengaruh signifikan terhadap pengguna website mobile di Malaysia. Hal ini memperkuat aturan nilai dan kegunaan teknologi dalam kinerja. Igbaria (1990) dan Robey et al. (1989) juga menemukan hal yang sama, yaitu adanya hubungan positif antara persepsi kemanfaatan dengan penggunaan sistem informasi

Mayoritas jawaban responden dalam penelitian ini menyebutkan bahwa menggunakan resep elektronik adalah hal yang mudah dilakukan. Davis et al. (1989) menemukan bahwa persepsi kemanfaatan mempunyai hubungan yang lebih kuat dan konsisten dengan penerimaan teknologi informasi dibandingkan dengan variabel lain, seperti sikap, kepuasan, dan ukuranukuran persepsian yang lain. Hasil penelitian yang dilakukan oleh Igbaria (1990) dan Robey et al. (1989) juga menemukan hal yang sama, yaitu adanya hubungan positif antara persepsi kemanfaatan dengan penggunaan sistem informasi.

Hipotesis 2 menyatakan bahwa persepsi kemudahan penggunaan berpengaruh terhadap sikap penggunaan resep elektronik oleh dokter di RSUD Prof. Dr. Margono Soekarjo Purwokerto. Hasil 
analisis regresi Tabel 4 menunjukan nilai thitung untuk variabel kemudahan penggunaan 2,180 dengan nilai signifikansi 0,033, karena nilai t hitung lebih besar dari t tabel 1,993 $(2,180>1,933)$ dan nilai signifikansi kurang dari 0,05 $(0,033<0,05)$, maka dapat disimpulkan bahwa hipotesis tersebut diterima. Hasil tersebut sejalan dengan penelitian yang dilakukan Tananjaya (2012) yang menyatakan bahwa proses implementasi software akuntansi pada biro perjalanan wisata di Surabaya tidak terlepas dari peran persepsi kemudahan pengguna yang juga mempengaruhi implementasi software akuntansi yang berkaitan dengan kepuasan penggunanya. Bulut et al., (2019) juga menyebutkan bahwa salah satu langkah paling penting dari program transformasi kesehatan melibatkan penerapan resep elektronik (e-prescription) dalam layanan kesehatan yang bertujuan untuk memberikan kemudahan penggunan bagi para tenaga medis.

Berdasarkan hasil tersebut membuktikan adanya pengaruh positif signifikan antara kemudahan penggunaan (perceived ease of use) berhubungan terhadap sikap terhadap penggunaan (attitude towards using). Hasil ini sesuai dengan penelitian yang dilakukan Tananjaya (2012) yang menyatakan bahwa proses implementasi software akuntansi pada biro perjalanan wisata di Surabaya tidak terlepas dari peran kemudahan penggunaan yang juga mempengaruhi implementasi software akuntansi yang berkaitan dengan kepuasan penggunanya.

Mayoritas jawaban responden dalam penelitian ini menyatakan bahwa sangat setuju bahwa menggunakan resep elektronik adalah hal yang mudah dilakukan. Sesuai dengan TAM, persepsi kemanfaatan juga dipengaruhi oleh kemudahan penggunaan karena semakin mudah suatu sistem digunakan maka sistem tersebut dirasakan semakin bermanfaat. Rasa mudah menggunakan sistem teknologi informasi akan menimbulkan perasaan dalam dirinya bahwa sistem itu mempunyai kegunaan, dan karenanya menimbulkan rasa nyaman bila bekerja dengan sistem teknologi informasi (Venkatesh et al., 2000). Dari berbagai pengujian empiris tentang TAM, kemudahan penggunaan secara konsisten merupakan faktor yang menentukan sikap user untuk menggunakan sistem.

Hipotesis 3 menyatakan bahwa dukungan organisasi berpengaruh terhadap sikap penggunaan resep elektronik oleh dokter di RSUD Prof. Dr. Margono Soekarjo Purwokerto. Hasil analisis regresi Tabel 4 menunjukan nilai t hitung untuk variabel dukungan organisasi 2,351 dengan nilai signifikansi 0,022 , karena nilai t hitung lebih besar dari t tabel 1,993 $(2,351>1,993)$ dan nilai signifikansi kurang dari 0,05 $(0,022<0,05)$, maka dapat disimpulkan bahwa hipotesis tersebut diterima. Hasil penelitian Bulut, et al (2018) juga menunjukkan hasil yang sama meskipun beberapa masalah dilaporkan mengenai penerapan resep elektronik pada bulanbulan pertama aplikasi, dokter keluarga yang berpartisipasi dalam penelitian ditemukan tetap setia dalam penerapan resep elektronik, dan mengidentifikasi efek positif pada pekerjaan dan proses mereka karena mendapat dukungan dari klinik tempatnya bekerja. Hal tersebut secara langsung membuktikan bahwa dukungan organisasi berhubungan terhadap sikap penggunaan resep elektronik.

Mayoritas jawaban responden dalam penelitian ini menyatakan bahwa rumah sakit sangat mempertimbangkan tujuan dan nilai dalam e-health teknologi. Artinya mayoritas setuju bahwa rumah sakit sangat mendukung para dokter dalam menggunakan resep elektronik karena merupakan implementasi tujuan dan nilai dalam e-health teknologi. Peresepan elektronik siwajibkan oleh pihak rumahsakit karena peresepan elektroni diterima secara positif oleh pasien dan penyedia layanan dan menghasilkan pengurangan total panggilan setelah jam kerja. Alasan lainnya mengapa pihak rumah sakit mendukung penggunaan peresepan elektronik adalah karena manfaat yang diakui dari peresepan elektronik adalah mengurangi kesalahan peresepan, meningkatkan keamanan resep, efisiensi praktik yang lebih besar, biaya obat yang lebih rendah, dan meningkatkan kepuasan pasien dan penyedia. Ketaatan pada pengobatan berbasis bukti memohon demonstrasi perbaikan seperti dari adopsi resep elektronik (Duffy, et al., 2010).

Hipotesis 4 menyatakan bahwa dukungan organisasi memediasi antara persepsi kemanfaatan terhadap sikap penggunaan resep elektronik oleh dokter di RSUD Prof. Dr. Margono Soekarjo 
Purwokerto. Berdasarkan Tabel 5 didapatkan hasil nilai signifikansi two-tailed probability $0,03401130<0,05$, artinya hipotesis tersebut diterima. Hasil tersebut sesuai dengan penelitian Penelitian AL-Gahtani dan King (1999) menyatakan bahwa variabel kemudahan penggunaan dalam pemanfaatan teknologi informasi memiliki pengaruh terhadap pemanfaatan melalui sikap mengenai teknologi yang dimediasi oleh dukungan dari berbagai pihak salah satunya yaitu dukungan yang berasal dari organisasi tempatnya bernaung (rumah sakit atau klinik).

Hasil tersebut sesuai dengan penelitian Penelitian AL-Gahtani dan King (1999) menyatakan bahwa variabel kemudahan penggunaan (perceived usefulness) dalam pemanfaatan teknologi informasi memiliki pengaruh terhadap pemanfaatan melalui sikap (attitude towards using) mengenai teknologi yang dimediasi oleh dukungan dari berbagai pihak salah satunya yaitu dukungan yang berasal dari organisasi tempatnya bernaung (rumah sakit/klinik). Mandasari (2017) menyatakan bahwa perceived usefulness berpengaruh positif dan signifikan terhadap kepuasan pengguna dalam hal ini dokter di RSUD Margono Soekarjo Purwokerto. Jika pengguna puas maka secara langsung akan mempengaruhi sikapnya terhadap penggunaan resep elektronik tersebut. Selain itu Tan dkk (2009), lebih dari 85\% dokter merasa puas dengan penggunaan resep elektronik. Kepuasan tersebut merupakan sikap yang ditunjukkan langsung oleh dokter. Menurut para dokter manfaat penggunaan resep elektronik adalah dapat melakukan deteksi kesalahan penulisan resep karena pihak rumah sakit mendukung melalui memberikan sistem yang baik sehingga dokter menerima alert untuk interaksi obat dan alergi obat pada pasien. Berdasarkan kedua penelitian tersebut artinya dapat disimpukan bahwa persepsi kemanfaatan (perceived usefulness) berhubungan terhadap sikap terhadap penggunaan (attitude towards using) yang melalui dukungan organisasi (perceived organizational support).

Hipotesis 5 menyatakan bahwa dukungan organisasi memediasi antara persepsi kemudahan penggunaan terhadap sikap penggunaan resep elektronik oleh dokter di RSUD Prof. Dr. Margono Soekarjo Purwokerto. Berdasarkan Tabel 6 didapatkan nilai signifikansi two-tailed probability 0,04472543<0,05, artinya hipotesis tersebut diterima. Hasil penelitian Robey et al. (1989) juga menemukan hal yang sama, yaitu adanya hubungan positif antara persepsi kemudahan pengggunaan dengan sikap penggunaan sistem informasi. Namun hubungan tersebut dipengaruhi juga oleh faktor eksternal seperti dukungan dari lembaga atau organisasi, karena jika dalam menggunakan resep elektronik tidak mendapat dukungan dari pihak rumah sakit, maka jika terjadi masalah perlu skill khusus untuk menyeleaikan kendala jika terjadi permsalahan pada TI.

Hasil penelitian ini juga sesuai yang dikemukakan oleh Hollingworth, et al., (2007) dimana resep elektronik telah meningkatkan kualitas dan keamanan perawatan karena kemudahan penggunaanya dan juga jika diterapkan dengan hati-hati, resep elektronik tidak akan sangat mengganggu alur kerja di rumah sakit, artinya dukungan dari organisasi dalam implementasi resep elektronik di rumah sakit sangat dibutuhkan agar kinerja sesuai yang diinginkan oleh organisasi. Peresepan elektronik sejauh ini telah meningkatkan dalam hal kualitas dan keamanan perawatan pasien, namun ada beberapa hambatan, salah satu penghalang yang signifikan adalah dampak potensial yang merugikan pada dokter dan alur kerja staf. Sehingga pihak rumah sakit perlu melakukan evaluasi terkait efisiensi waktu dari peresepan elektronik dalam perawatan rawat jalan.

\section{KESIMPULAN}

Persepsi kemanfaatan berhubungan terhadap sikap penggunaan resep elektronik. Berdasarkan hasil tersebut membuktikan adanya hubungan positif antara persepsi kemanfaatan terhadap sikap penggunaan resep elektronik. Persepsi kemanfaatan dari layanan resep elektronik yang diterapkan dengan benar diharapkan memberikan akses yang lebih baik bagi warga masyarakat tentang perawatan kesehatan yang berkualitas lebih tinggi, selain itu dapat meningkatkan efisiensi untuk sistem kesehatan. Resep elektronik juga mempunyai manfaat yaitu untuk mentransfer data antara penyedia layanan kesehatan kepada apotekapotek. 
Persepsi kemudahan penggunaan berhubungan terhadap sikap penggunaan resep elektronik. Berdasarkan hasil tersebut membuktikan adanya pengaruh positif signifikan antara persepsi kemudahan penggunaan berhubungan terhadap sikap penggunaan resep elektronik.

Dukungan organisasi berhubungan terhadap sikap penggunaan resep elektronik. Berdasarkan hasil tersebut membuktikan adanya pengaruh positif signifikan antara kemauan mengambil resiko terhadap kinerja pegawai.

Persepsi kemanfaatan berhubungan terhadap sikap penggunaan resep elektronik yang dimediasi oleh dukungan organisasi. Hasil tersebut menunjukkan bahwa persepsi kemanfaatan terbukti dapat menjelaskan alasan seseorang dalam menggunakan sistem informasi dan menjelaskan bahwa sistem baru yang sedang dikembangkan diterima oleh pengguna. Artinya dapat disimpukan bahwa persepsi kemanfaatan berhubungan terhadap sikap terhadap penggunaan melalui dukungan organisasi.

Kemudahaan penggunaan berhubungan terhadap sikap penggunaan resep elektronik melalui dukungan organisasi. Sehingga secara langsung persepsi kemudahan pengggunaan berhubungan dengan sikap terhadap penggunaan resep elektronik melalui dukungan organisasi.

\section{IMPLIKASI}

Hasil penelitian ini memperkuat hasil penelitian yang pernah dilakukan sebelumnya bahwa persepsi kemanfaatan dan kemudahan penggunaan berhubungan terhadap sikap terhadap penggunaan terhadap resep elektronik oleh dokter di RSUD Margono Soekarjo Purwokerto, selain itu dukungan organisasi memediasi antara hubungan persepsi kemanfaatan dan kemudahan penggunaan berhubungan terhadap sikap terhadap penggunaan terhadap resep elektronik.

Kemudahan penggunaan dan persepsi kemanfaatan menurut Bulut, et al., (2018). sangat berkaitan terutama mengenai penggunaan resep elektronik. Karena resep elektronik merupakan salah satu langkah paling penting dari program transformasi kesehatan dalam layanan kesehatan. Sehingga peresepan elektronik perlu diterapkan dengan baik di RSUD Margono Soekarjo Purwokerto sebagai aplikasi kontribusi untuk resep dan pasien.

Sikap seorang individu berhubungan dengan beberapa faktor salah satunya yaitu faktor lingkungan seperti organisasi tempatnya bernaung. Rumah sakit sebagai organisasi tempatnya para dokter bekerja sangat mendukung penggunaan resep elektronik sehingga mempengaruhi sikap para penggunanya. Sehingga pihak RSUD Margono Soekarjo Purwokerto perlu mendukung secara maksimal dalam penggunaan resep elektronik agar keselamatan pasien dapat ditingkatkan melalui penggunaan resep elektronik dengan meningkatkan keterbacaan resep, serta mengurangi waktu yang diperlukan untuk meresepkan obat dan mengurangi kesalahan pemberian obat dan mengurangi efek samping obat.

\section{SARAN}

Pengembangan penggunaan resep elektronik di RSUD Margono Soekarjo Purwokerto perlu dipertimbangkan faktor perceived usefulness dan perceived ease of use dari pengguna terhadap sistem informasi tersebut.

RSUD Margono Soekarja Purwokerto sebaiknya lebih terbuka dengan karyawannya dalam hal ini yaitu para tenaga medis yang berhubungan dengan penggunaan resep elektronik karena hal ini dapat meningkatkan sikap terhadap penggunaan resep elektronik.

\section{DAFTAR PUSTAKA}

$\underline{B u k u}$

Arikunto, Suharsimi, 2002. Prosedur Penelitian Suatu Pendekatan Praktek. PT. Rineka Cipta. Jakarta. 
Eisenberger, R., \& Stinglhamber, F. 2011. Perceived organizational support: Fostering enthusiastic and productive employees. Washington, DC: American Psychological Association Books.

Igbaria, M., Saroj Parasuraman., dan Michael K. Badaway. 1994. Work Experience, Job Involvement, and Quality of Work Life Among Information Systems Personnel. MIS Quarterly, Juni, 175-201 hal.

Jogiyanto. 2008. Metodologi Penelitian Sistem Informasi. Yogyakarta: CV Andi Offset.

Malhotra, N.K. 2009. Riset Pemasaran, Edisi keempat, Jilid 1. Jakarta: PT Indeks.

Sugiyono. 2011. Metode Penelitian Kuantitatif, Kualitatif dan R\&D. Bandung: Alfabeta.

Tan WS, Phang JSK, Tan LK. Evaluating user satisfaction with an electronic prescription system in a primary care group. Ann Acad Med Singapore 2009;38:494-500.

Widiastuti, Margareta. 2013. Peran Resep Elektronik dalam Upaya Meningkatkan Medication Safety pada Proses Prescribing. Yogyakarta: UGM Perss.

Jurnal Ilmiah

Aldrich, Krista dan Kumar, Sameer. 2010. Overcoming Barriers to Electronic Medical Record (EMR) Implementation in the us Healthcare System: A Comparative Study. Health Informatics Journal Vol 16 (4): 306-318.

Bulut, S., Ahmet Y., Sidika, K., 2019. Evaluation of Transition to Electronic Prescriptions in Turkey: Perspective of Family Physicians. International Journal Health Policy Manag Vol $8(1), 40-48$.

Davis, F.D. 1989. Perceived Usefulness, Perceived Ease of Use, and User Acceptance of Information Technology. Management Information Systems Quarterly. Vol 13(3). 319-340.

Chang, M. Y., Chuan P., Michael J. T., Liu, T. C., David C. Y. 2015. Exploring user acceptance of an e-hospital service: An empirical study in Taiwan. Journal Computer Standards \& Interfaces Vol 38 hal; 35-43.

Dalbouh, H.M. 2013. A Questionnaire Approach Based On The Technolog Acceptance Model For Mobile Tracking On Patient Progress Applications, Journal of Computer Science Vol 9 (6): 763-770.

Dobrzanski B., Bartlett DW, Clough MJ, Godwin JR, Hall AA, Hamer M. 2002 Review, the Strobilurin Fungicides. Pest Management Science. Vol 58: 649-662

Eisenberger, R., Huntington, R., Hutchison, S., \& Sowa, D. 1986. Perceived Organizational Support. The Journal of Applied Psychology, Vol 71(3), 500-507.

Eisenberger, R., Armeli, S., Rexwinkel, B., Lynch, P. D., \& Rhoades, L. 2001. Reciprocation of Perceived Organizational Support. Journal of Personnel Psychology. Vol 86(1). 42-51.

Farida, S., Desak G. B., Krisnamurti, Rani W. K., Adisti D., Erni H. P. 2017. Implementasi Peresepan Elektronik. Jurnal Fakultas Kedokteran Universitas Indonesia Vol. 5, No. 3, Desember 2017. 
Huang, W., D'Ambra, J. and Bhalla, V. 2000. An Empirical Investigation of The Adoption of EGovernment in Australian Citizens: Research Finding. The Journal of Computer Information System, Vol 43 (1): 15-22.

Holroyd-Leduc, J. M., Sen, S., Bertenthal, D., Sands, L. P., Palmer, R. M., Kresevic, D. M., et al. 2011. The Relationship of Indwelling Urinary Catheters to Death, Length of Hospital Stay, Functional Decline, and Nursing Home Admission in Hospitalized Older Medical Patients. Journal of the American Geriatrics Society, Vol 55: 227-233.

Holroyd-Leduc, J. M., L. Diane, E. S. Sharon, S. Lindsay, dan Q. Hude. 2011. The impact of the electronic medical record on structure, process, and outcomes within primary care: A systematic review of the evidence. The Journal of the American Medical Informatics Association Vol 18: 732-737.

Kim Y., \& Hyung S.L. 2014. Quality, Perceived Usefulness, User Satisfaction, and Intention to Use: An Empirical Study of Ubiquitous Personal Robot Service. Asian Social Science. Vol.10. No. 11. pp.1-16.

Radley, D. C. 2013. Reduction in medication errors in hospitals due to adoption of computerized provider order entry systems. The Journal of the American Medical Informatics Association Vol 20: 1-7.

Rhoades, L., \& Eisenberger, R. 2002. Perceived organizational support: a review of the literature. Journal of Applied Psychology Vol 87(4), 698-714.

Tananjaya, V.A. 2012. Kualitas Sistem Informasi, Kualitas Informasi, Dan Perceived Usefulness Terhadap Keberhasilan Implementasi Software Akuntansi. Berkala Ilmiah Mahasiswa Akuntansi, Vol.1. No.3. pp.1-16.

Venkatesh, V. and Morris, M. G. 2000. Why Don't Men Ever Stop do Ask Direction? Gender, Social Influence. Management Information Systems Quarterly, Vol 24 (1): 115-139.

Wayne, S.J., Shore, L.M.., \& Liden, R.C. 1997. Perceived Organizational Support and LeaderMember Exchange: A Social Exchange Perspective. Journal of Management Journal, Vol 40: 82-111. 
Pegaruh Persepsi Kemanfaatan dan Persepsi Kemudahan Penggunaan Terhadap Sikap Penggunaan Resep Elektronik 
Jurnal Ekonomi, Bisnis dan Akuntansi (JEBA) Volume 22 No 2 Tahun 2020 